\title{
Front Matter: Volume 11802
}

, "Front Matter: Volume 11802," Proc. SPIE 11802, Nanoengineering: Fabrication, Properties, Optics, Thin Films, and Devices XVIII, 1180201 (24 August 2021); doi: 10.1117/12.2606444

SPIE Event: SPIE Nanoscience + Engineering, 2021, San Diego, California, United SPIE. States 


\section{PROCEEDINGS OF SPIE}

\section{Nanoengineering: Fabrication, Properties, Optics, Thin Films, and Devices XVIII}

Balaji Panchapakesan

André-Jean Attias

Wounjhang Park

Editors

1-5 August 2021

San Diego, California, United States

Sponsored and Published by

SPIE 
The papers in this volume were part of the technical conference cited on the cover and title page. Papers were selected and subject to review by the editors and conference program committee. Some conference presentations may not be available for publication. Additional papers and presentation recordings may be available online in the SPIE Digital Library at SPIEDigitalLibrary.org.

The papers reflect the work and thoughts of the authors and are published herein as submitted. The publisher is not responsible for the validity of the information or for any outcomes resulting from reliance thereon.

Please use the following format to cite material from these proceedings:

Author(s), "Title of Paper," in Nanoengineering: Fabrication, Properties, Optics, Thin Films, and Devices XVIII, edited by Balaji Panchapakesan, André-Jean Attias, Wounjhang Park, Proc. of SPIE 11802 , Seven-digit Article CID Number (DD/MM/YYYY); (DOI URL).

ISSN: 0277-786X

ISSN: 1996-756X (electronic)

ISBN: 9781510644427

ISBN: 9781510644434 (electronic)

Published by

SPIE

P.O. Box 10, Bellingham, Washington 98227-0010 USA

Telephone +1 3606763290 (Pacific Time)

SPIE.org

Copyright (C) 2021 Society of Photo-Optical Instrumentation Engineers (SPIE).

Copying of material in this book for internal or personal use, or for the internal or personal use of specific clients, beyond the fair use provisions granted by the U.S. Copyright Law is authorized by SPIE subject to payment of fees. To obtain permission to use and share articles in this volume, visit Copyright Clearance Center at copyright.com. Other copying for republication, resale, advertising or promotion, or any form of systematic or multiple reproduction of any material in this book is prohibited except with permission in writing from the publisher.

Printed in the United States of America by Curran Associates, Inc., under license from SPIE.

Publication of record for individual papers is online in the SPIE Digital Library.

\section{SP|E. DIGITAL}

Paper Numbering: A unique citation identifier (CID) number is assigned to each article in the Proceedings of SPIE at the time of publication. Utilization of CIDs allows articles to be fully citable as soon as they are published online, and connects the same identifier to all online and print versions of the publication. SPIE uses a seven-digit CID article numbering system structured as follows:

- The first five digits correspond to the SPIE volume number.

- The last two digits indicate publication order within the volume using a Base 36 numbering system employing both numerals and letters. These two-number sets start with 00, 01, 02, 03, 04, 05, 06, 07, 08, 09, OA, OB ... 0Z, followed by 10-1Z, 20-2Z, etc. The CID Number appears on each page of the manuscript. 


\section{Contents}

NANOSTRUCTURED THIN FILMS

$1180202 \quad$ Morphological effects on the excitation of surface waves in the grating-coupled configuration [1 1802-18]

$1180205 \quad$ Fabrication of plasmonic nanoslit aperture platform for biomolecule analysis [11802-15]

1180206 Introducing 'low cost large scale' hydrophobic SERS substrate [1 1802-16]

NANO- AND MICRO-OPTICS

$11802 \mathrm{OB} \quad$ Characterization of the optical performance and scatter of an infrared dielectric metasurface lens [1 1802-27]

11802 0C A method to improve the optical coupling into the bioinspired peptide micro-waveguides using aberrated objective [1 1802-24]

11802 OD High-uniformity dielectric U-shaped surface relief grating coupler for AR headsets [1 1802-25]

11802 OE Self-stabilisation of a resonance of microresonator based on optical fibre with active core [1 1802-26]

\section{POSTER SESSION}

$11802 \mathrm{OL} \quad$ The polymer nanocomposites embedded particles size and agglomeration effect on the effective refractive index tuning [11802-55]

11802 ON A silicon integrated photonic sensor using Bragg gratings and signal post-processing [1 1802-35]

1180200 A small footprint Y-branch power splitter based on simplified coherent coupling on Silicon Nitride [1 1802-36]

11802 OP Modelling of thermophysical phenomena at cutting tools with thin self-organising coatings [1 1802-37]

$118020 Q \quad$ Extraordinary enhancement of the transverse magneto-optical Kerr effect with high-refractiveindex nanostructures [11802-38]

11802 OR Electrically conductive nanocomposite films deposition and electrical discharge machining of ceramic surfaces to generate functional microtextures [1 1802-39] 
11802 OT Effect of PACVD deposition of nitride and Si-containing amorphous hydrogenated carbon films on the tribological characteristics of SiAION ceramics [11802-41]

11802 OU Single-tunable and dual-wavelength operation of a passive Q-switch double-Clad Er-Yb fiber laser based on the use of a titanium-oxynitride-coated fiber ball lens [1 1802-43]

$11802 \mathrm{OV}$ Combined processing of optical parts through surface polishing with a beam of fast argon atoms and deposition of nanostructured protective films by magnetron target sputtering [11802-44]

$11802 \mathrm{OW} \quad$ Validation of the effects of growth parameter variations on the optical characteristics of InAs QD through Nextnano simulations [1 1802-45]

$118020 \mathrm{X}$ On the reconfigurable phase change medium-based hyperbolic metamaterials [11802-46]

11802 oY Graphene-strontium titanate-based metamaterial for optical sensing [1 1802-47]

$118020 Z$ Polarization effects analysis in tilted subwavelength periodical waveguides [11802-49]

1180210 Gray wolf optimization of photonics crossing waveguides [1 1802-50]

1180211 Polarization-insensitive optical modulators based on single ENZ-graphene layers [11802-51]

1180212 Thermal effects in hybrid optical photonic organic devices [11802-52]

1180213 Flexible and optically transparent radio frequency antennas enabled by metallic meshes [11802-53]

$1180214 \quad$ Green synthesis of silver nanoparticles by pulsed laser ablation using citrus limetta juice extract for clad-modified fiber optic gas sensing application [1 1802-54] 